\title{
Comparative Evaluation of Changes in Protein Profile of Sugarcane Varieties under Different Soil Moisture Regimes
}

\author{
Pooja $^{{ }^{*}}$, A. S. Nandwal ${ }^{1}$, Mehar Chand ${ }^{2}$, Ashwani Kumar ${ }^{3}$, Babita Rani ${ }^{1}$, \\ Anita Kumari ${ }^{1}$ and Neeraj Kulshrestha ${ }^{4}$ \\ ${ }^{1}$ CCS Haryana Agricultural University, Hisar - 125004, Haryana, India \\ ${ }^{2}$ Regional Research Station, CCS HAU, Karnal - 132001, Haryana, India \\ ${ }^{3}$ ICAR-Central Soil Salinity Research Institute, Karnal - 132001, Haryana, India \\ ${ }^{4}$ ICAR-Sugarcane Breeding Institute, Regional Centre, Karnal - 132001, Haryana, India \\ *Corresponding author
}

\begin{tabular}{|c|c|}
\hline & A B S T R A C T \\
\hline & \\
\hline Keywords & $\begin{array}{l}\text { protein profiles under control ( } 50 \% \text { ASM), moisture stress of } 40 \% \text { ASM (mild stress) and } \\
30 \% \text { ASM (severe stress). Both qualitative and quantitative differences were observed. }\end{array}$ \\
\hline $\begin{array}{l}\text { Available soil } \\
\text { moisture, Water } \\
\text { deficit, Polypeptides, } \\
\text { Protein profile, } \\
\text { Sugarcane. }\end{array}$ & $\begin{array}{l}\text { Total soluble proteins content in leaves significantly increased at both } 40 \% \text { ASM levels } \\
(21.05 \text { and } 27.19 \%) \text { and } 30 \%(27.15 \text { and } 43.44 \%) \text { as compared to } 50 \% \text { ASM level at } 60 \\
\text { and } 90 \text { DAP, respectively. Severe stress of } 30 \% \text { ASM levels caused formation of new } \\
\text { protein band of MW } 18.56,13.46,31.6 \text { and } 36.6 \mathrm{kDa} \text { in leaves of variety Co } 0238 \text {. In CoJ }\end{array}$ \\
\hline Article Info & $\begin{array}{l}\text { 64, one new polypeptide band of MW } 38.5 \mathrm{kDa} \text { appeared and two polypeptide bands of } \\
\text { MW } 13.6 \text { and } 18.56 \mathrm{kDa} \text { disappeared. Variety CoS } 767 \text { showed the presence of four new }\end{array}$ \\
\hline $\begin{array}{l}\text { Accepted: } \\
\text { 10 August } 2017 \\
\text { Available Online: } \\
10 \text { October } 2017\end{array}$ & $\begin{array}{l}\text { band of } 13.46,15.6,18.56 \text { and } 38.2 \mathrm{kDa} \text {. Likewise in variety } \mathrm{CoH} 128 \text { two new } \\
\text { polypeptide bands of MW } 25.2 \text { and } 26.8 \mathrm{kDa} \text { appeared and } 4 \text { band of MW } 13.46,15.6 \text {, } \\
18.17 \text { and } 54.6 \mathrm{kDa} \text { disappeared at } 30 \% \text { and } 40 \% \text { ASM levels. Appearance of new } \\
\text { polypeptide(s) or their disappearance might be related to the genotypic stress tolerance or } \\
\text { sensitivity. }\end{array}$ \\
\hline
\end{tabular}

\section{Introduction}

Sugarcane, a crop of great worldwide economic importance, accounts for approximately $75 \%$ of the global sugar production (Commodity Research Bureau, 2015). Being a high water demanding crop, sugarcane has necessitated the need to evolve drought tolerant varieties to sustain sugarcane production. Water is the major constituent of cane and approximately 2.97 lakh ha of cane area is prone to drought affecting the crop at one or other stage of growth in every state of India (Vision SBI, 2016). Water stress elicits a complex of responses beginning with stress perception, which initiates a signal transduction pathway(s) and causes multifaceted changes at the cellular, physiological and developmental levels (Bray, 2001). During drought, plant water status, water conductance and conservation are controlled by different mechanisms and protein synthesis plays major role as a biochemical signal in the adaptive response of plants (Singh et al., 2013). SDS-PAGE is most economical simple and extensively used 
biochemical technique for analysis of genetic structure of germplasm. The importance of protein profiling has long been acknowledged in plant abiotic stress studies and previous studies (Kiegel et al., 2000) have provided useful information on stress-dependent changes in quantity, activity, as well as modifications of structural protein, proteinprotein interactions, stress dependent protein movements, de novo synthesis and controlled degradation which in turn suggested that many proteins are specifically altered de novo under water stress as a part of the adaptive mechanism. There is net synthesis of some proteins and decrease in the others, with or without induction of unique stress proteins. These stress-induced proteins allow plants to make biochemical and structural adjustments that enable them to cope with stress (Chandra and Tyagi, 2004).

Proteins which are synthesized in response to drought stress are called dehydrin (dehydration-induced). Most investigation on plants grown under drought stress showed the evidence of dehydrin proteins with molecular weight ranging from $22-60 \mathrm{kDa}$. These stress-induced proteins are involved in the biosynthesis of osmolytes, uptake and compartmentation of ions, hydroxyl-radical scavenging and protection of cellular structure (Joshi et al., 2013). Thus, understanding the biochemical and molecular basis of drought tolerance will be helpful in developing strategies for improving drought tolerance in sugarcane. The present study was undertaken to see the effect of water stress on protein profiles of four sugarcane varieties differing in their maturity.

\section{Materials and Methods}

To study the effect of irrigations at different available soil moisture (ASM) levels on four sugarcane varieties, two under mid late group viz., $\mathrm{CoH}$ 128, CoS 767 and two under early group viz., Co 0238 and CoJ 64. After complete germination (40 days after planting), three levels of ASM were created i.e. irrigation at 50\% ASM level (control), irrigation at $40 \%$ ASM level (mild stress) and irrigation at 30\% ASM level (severe stress). These ASM levels were created only during pre-monsoon (in the month of April, May and June) period by withholding irrigation and later on i.e. post monsoon period (in the month of July), the crop was irrigated for stress revival as per requirement. Sampling was done at 60, 90 and 120 days after planting (DAP).

\section{Extraction and determination of soluble proteins}

One gram fresh samples from first TVD leaf was homogenized with the help of pre-chilled pestle and mortar in $2.5 \mathrm{ml}$ of chilled tris buffer $(0.1 \mathrm{M}, \mathrm{pH} \quad 8.0)$ containing $0.1 \%$ polyvinyl pyrrolidone (PVP). The homogenate were then centrifuged at $10,000 \mathrm{~g}$ at $4{ }^{\circ} \mathrm{C}$ for $15 \mathrm{~min}$. The supernatant containing the proteins was taken in a chilled test tube. The amount of protein in the extract was determined following Bradford (Bradford, 1976).

\section{Protein profile resolution (SDS-PAGE)}

A $25 \mu \mathrm{l}$ of crude protein extract, containing $50 \mu \mathrm{g}$ of protein extract was transferred to an equal volume of Laemmli's $2 \mathrm{X}$ sample buffer (0.5 M Tris-HCl, pH 6.8) containing $20 \%$ glycerol, $4 \%$ SDS, $0.5 \%$ bromophenol blue $(\mathrm{w} / \mathrm{v})$ and $10 \% \beta$-mercaptoethanol and heated at $100^{\circ} \mathrm{C}$ for $3 \mathrm{~min}$ and cooled. Electrophoresis was carried out by the method of Laemmli (Laemmli et al., 1970). The cooled samples were then loaded on to a SDS-discontinuous gel system with a $0.1 \mathrm{~mm}$ thick stacking gel of $4 \%$ polyacrylamide in Tris- $\mathrm{HCl}$ buffer ( $\mathrm{pH}$ 6.8) and a resolving gel of $10 \%$ polyacrylamide in Tris- $\mathrm{HCl}$ buffer 
(pH 8.8). The gels were run at $15 \mathrm{~mA}$ in the stacking gel and $25 \mathrm{~mA}$ in the resolving gel. After electrophoresis, gels were fixed and stained with $0.25 \%(\mathrm{w} / \mathrm{v})$ Coomassie Brilliant Blue R-250 in $40 \%(\mathrm{v} / \mathrm{v})$ methanol with $7 \%$ glacial acetic acid (v/v) and then destained in $10 \%$ methanol (v/v) with $7.5 \%$ glacial acetic acid (v/v). After destaining, the gels were stored at $7 \%$ glacial acetic acid (v/v).

\section{Statistical analysis}

All the data were subjected to variance analysis using the SAS (Version 9.3, SAS Institute Inc., Cary, NC, USA). Least significant difference test was applied at 5 per cent probability level to compare the mean differences.

\section{Results and Discussion}

Total soluble proteins content in leaves significantly increased at both $30 \%$ (27.15 and $43.44 \%$ ) and 40\% ASM levels (21.05 and $27.19 \%$ ) as compared to $50 \%$ ASM level at 60 and 90 DAP, respectively. At 30\% ASM level, significantly higher proteins content was recorded in variety Co $0238\left(13.7 \mathrm{mg} \mathrm{g}^{-1}\right.$ DW) followed by $\mathrm{CoH} 128\left(13.36 \mathrm{mg} \mathrm{g}^{-1}\right.$ DW) and CoS 767 (11.71 $\left.\mathrm{mg} \mathrm{g}^{-1} \mathrm{DW}\right)$ whereas the lowest value was recorded in CoJ 64 (8.67 $\left.\mathrm{mg} \mathrm{g}^{-1} \mathrm{DW}\right)$. After stress revival (at 120 DAP), non-significant difference was recorded at $30 \%$ and $40 \%$ ASM levels as compared to $50 \%$ ASM level (Table 1).

The alteration of protein synthesis or degradation is one of the fundamental metabolic processes that affect drought tolerance. Comparative evaluation of changes in protein profile was performed in sugarcane varieties (Co 0238, CoJ 64, CoH 128 and $\mathrm{CoS}$ 767) using SDS-PAGE analysis. The effect of different ASM levels were studied at different stages i.e. 60 DAP, 90 DAP and 120 DAP (stress revival) and clear differences was seen in protein profile pattern by the presence or absence bands to varied intensity of expression. At 60 DAP, in variety Co 0238 , two new bands of MW 36.6 and $31.6 \mathrm{kDa}$ appeared and in case of $\mathrm{CoJ} 64$, one new polypeptide band of MW $38.5 \mathrm{kDa}$ appeared at $30 \%$ ASM level. Whereas in $\mathrm{CoH} 128$, two new polypeptide bands of 26.8 and $25.2 \mathrm{kDa}$ appeared at 30\% ASM level and CoS 767 showed the presence of one new band of 38.2 $\mathrm{kDa}$ at $30 \%$ ASM level and 40\% ASM level in comparison to $50 \%$ ASM level (Figure 1).

These proteins might be synthesized either $d e$ novo in response to drought stress or may be present constitutively at low concentration and increase when these varieties were exposed to higher stresses. At 90 DAP, one new polypeptide band of MW $18.56 \mathrm{kDa}$ appeared at $40 \%$ ASM level and one new band of MW $13.46 \mathrm{kDa}$ appeared at $30 \%$ ASM level in Co 0238 whereas in CoJ 64, two polypeptide bands of MW 18.56 and 13.6 $\mathrm{kDa}$ disappeared at $30 \%$ ASM level. On the other hand in variety $\mathrm{CoH} 128$, one band of MW $13.46 \mathrm{kDa}$ disappeared at 40\% ASM level and disappearance of 3 polypeptide bands of MW 54.6, 18.17 and 15.6 kDa was observed at $30 \%$ ASM level and in variety $\mathrm{CoS} 767$, denovo synthesis of two new bands of MW 15.6 and $13.46 \mathrm{kDa}$ were observed at 40\% ASM level (Figure 2).

Such modifications might led to accumulation or depletion of certain metabolites resulting in an imbalance in the levels of a relatively small set of cellular proteins, which could increase, decrease, appear or disappear after stress treatment (Kumar et al., 2015). Upon stress revival (120 DAP), no significant effect of different ASM levels were observed on protein profiling of different sugarcane varieties (Fig. 3). These results showed that varietal behaviour to moisture stress/drought was dependent on nature and concentration of stresses involved. 
Table.1 Effect of different soil moisture regimes on total soluble protein content $\left(\mathrm{mg} \mathrm{g}^{-1} \mathrm{DW}\right)$ in sugarcane varieties differing in their maturity group

\begin{tabular}{|c|c|c|c|c|c|c|c|c|c|c|c|c|c|c|c|}
\hline \multirow{2}{*}{ Varieties/Treatments } & $\begin{array}{c}\text { CoH } \\
128\end{array}$ & $\begin{array}{c}\text { CoS } \\
767\end{array}$ & $\begin{array}{c}\text { Co } \\
0238\end{array}$ & $\begin{array}{c}\text { CoJ } \\
64\end{array}$ & Mean & $\begin{array}{c}\text { CoH } \\
128\end{array}$ & $\begin{array}{l}\text { CoS } \\
767\end{array}$ & $\begin{array}{c}\text { Co } \\
0238\end{array}$ & $\begin{array}{c}\text { CoJ } \\
64\end{array}$ & Mean & $\begin{array}{c}\text { CoH } \\
128\end{array}$ & $\begin{array}{l}\text { CoS } \\
767\end{array}$ & $\begin{array}{c}\text { Co } \\
0238\end{array}$ & $\begin{array}{c}\text { CoJ } \\
64\end{array}$ & Mean \\
\hline & \multicolumn{5}{|c|}{ LAI after 30 - 60 DAP } & \multicolumn{5}{|c|}{ LAI after 30 - 60 DAP } & \multicolumn{5}{|c|}{ LAI after 90 - 120 DAP (stress revival) } \\
\hline $\begin{array}{l}\text { Irrigation at } 50 \% \\
\text { ASM (Control) }\end{array}$ & 7.64 & 8.85 & 8.83 & 8.13 & $8.36^{B}$ & 11.65 & 8.26 & 10.24 & 8.23 & $9.6^{\mathrm{C}}$ & 9.50 & 8.90 & 10.61 & 9.43 & 9.61 \\
\hline $\begin{array}{l}\text { Irrigation at } 40 \% \\
\text { ASM (Mild stress) }\end{array}$ & 8.52 & 10.48 & 13.18 & 8.32 & $10.12^{\mathrm{A}}$ & 13.18 & 13.16 & 13.95 & 8.57 & $12.21^{\mathrm{B}}$ & 8.26 & 9.09 & 9.48 & 9.30 & 9.03 \\
\hline $\begin{array}{l}\text { Irrigation at } 30 \% \\
\text { ASM (Severe stress) }\end{array}$ & 9.07 & 10.80 & 13.97 & 8.70 & $10.63^{\mathrm{A}}$ & 15.25 & 13.73 & 16.89 & 9.21 & $13.77^{\mathrm{A}}$ & 8.37 & 8.98 & 9.93 & 9.75 & 9.26 \\
\hline Mean & $8.41^{\mathrm{C}}$ & $10.04^{B}$ & $11.99^{A}$ & $8.38^{\mathrm{C}}$ & & $13.36^{\mathrm{A}}$ & $11.71^{\mathrm{B}}$ & $13.7^{\mathrm{A}}$ & $8.67^{\mathrm{C}}$ & & $8.71^{\mathrm{C}}$ & $8.99^{\mathrm{BC}}$ & $10^{A}$ & $9.49^{\mathrm{AB}}$ & \\
\hline $\mathrm{CV}$ & \multicolumn{5}{|c|}{ Varieties $-7.92 ;$ Treatments -6.06} & \multicolumn{5}{|c|}{ Varieties -3.857 ; Treatments -2.352} & \multicolumn{5}{|c|}{ Varieties -5.67 ; Treatments -5.572} \\
\hline LSD & $\begin{array}{l}\mathrm{V}- \\
0.76\end{array}$ & $\mathbf{T}-\mathbf{0 . 6 7}$ & \multicolumn{2}{|c|}{$\begin{array}{c}\mathrm{T} \times \mathrm{V}- \\
1.32\end{array}$} & $\begin{array}{c}\mathrm{V} \times \mathrm{T}- \\
\mathbf{1 . 3 1}\end{array}$ & $\mathrm{V}-\mathbf{0 . 4 5}$ & \multicolumn{2}{|c|}{$\mathbf{T}-\mathbf{0 . 3 2}$} & $\begin{array}{c}\mathrm{T} \times \mathrm{V}- \\
0.75\end{array}$ & $\begin{array}{l}\mathrm{V} \times \mathrm{T}- \\
0.78\end{array}$ & $\mathrm{~V}-\mathbf{0 . 5}$ & $\mathbf{T}-\mathbf{N S}$ & \multicolumn{2}{|c|}{$\mathbf{T} \times \mathbf{V}-$} & $\begin{array}{l}\mathrm{V} \times \mathrm{T}- \\
\mathrm{NS}\end{array}$ \\
\hline
\end{tabular}

Least significant difference test was applied at 5 per cent probability level to compare the mean differences.

(ASM - Available Soil Moisture; V - Varieties; T - Treatments; $\mathrm{T} \times \mathrm{V}$ - Treatments at the same level of varieties; V $\times \mathrm{T}-\mathrm{Varieties}$ at the same level of treatments) 
Fig.1 Effect of different soil moisture regimes on polypeptide resolution (A) early sugarcane varieties (Co 0238; CoJ64) and (B) mid-late sugarcane varieties (CoH 128; $\mathrm{CoS} 767)$ at $60 \mathrm{DAP}$
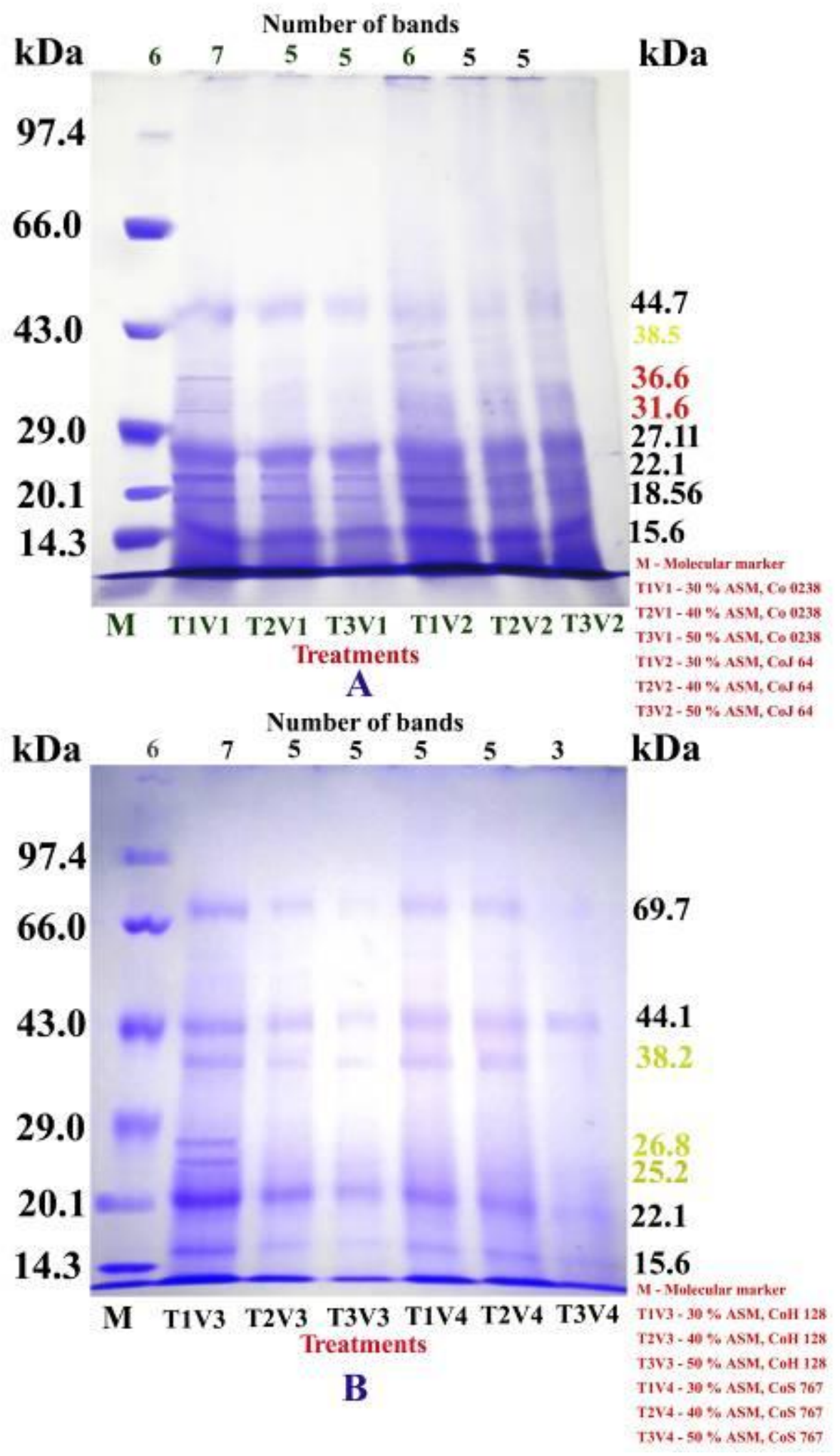
Fig.2 Effect of different soil moisture regimes on polypeptide resolution (A) early sugarcane varieties (Co 0238; CoJ64) and (B) mid-late sugarcane varieties ( $\mathrm{CoH} 128 ; \mathrm{CoS} 767)$ at $90 \mathrm{DAP}$

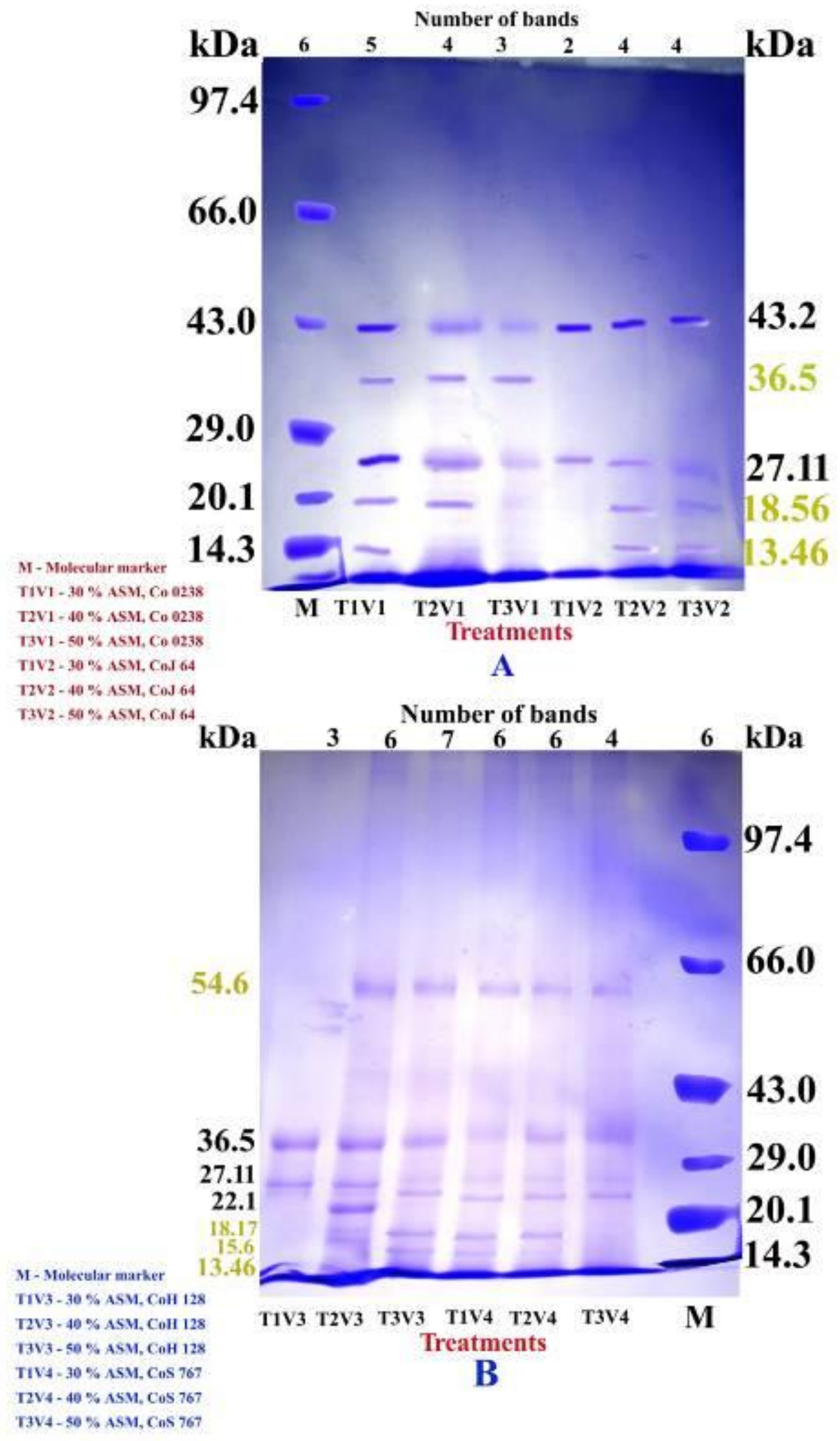


Fig.3 Effect of different soil moisture regimes on polypeptide resolution (A) early sugarcane varieties (Co 0238; CoJ64) and (B) mid-late sugarcane varieties ( $\mathrm{CoH} 128 ; \mathrm{CoS} 767)$ at 120

DAP (stress revival)

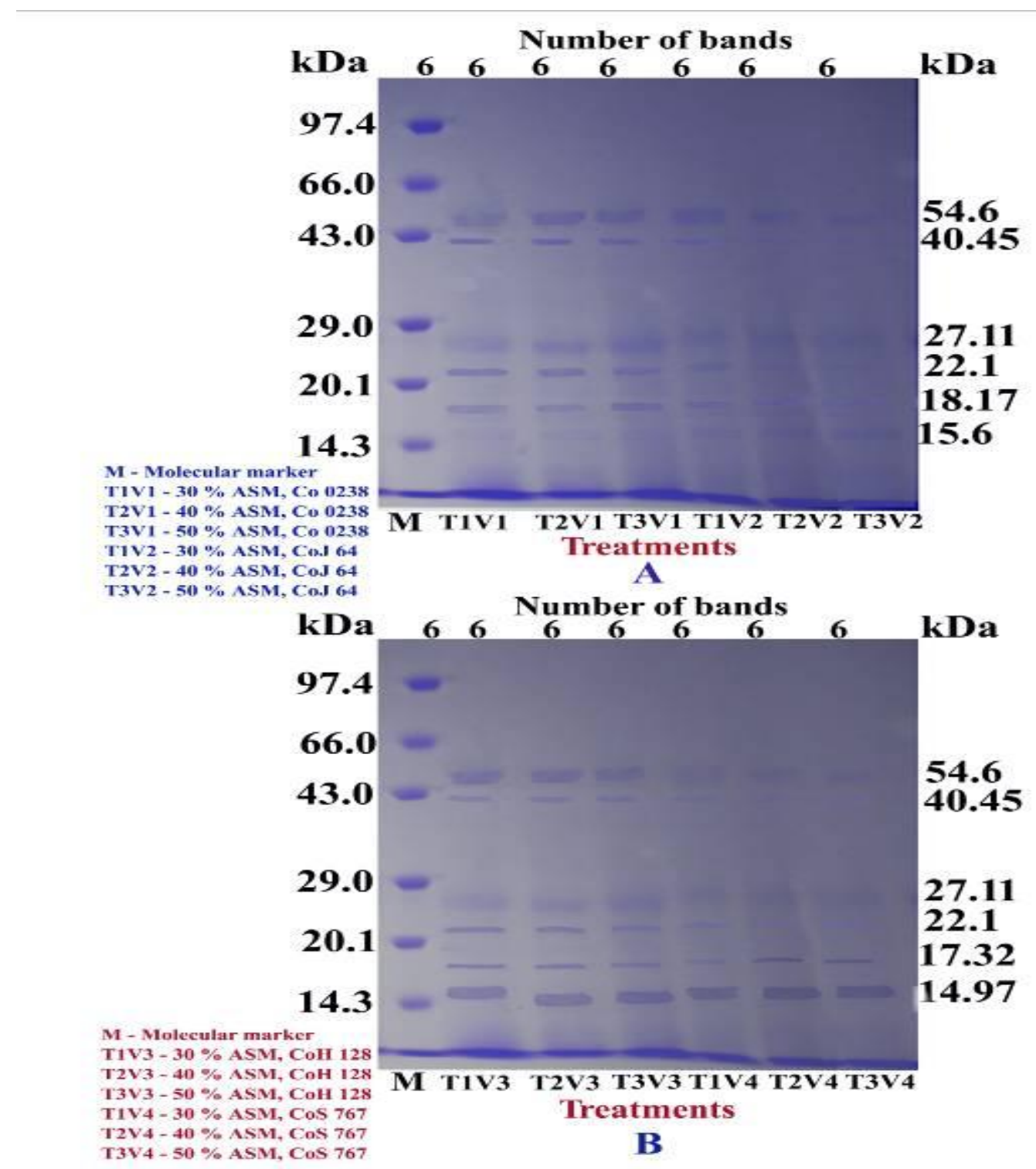

The bands which were present in the treated plants may be inherently associated with germination and growth processes. Their disappearance may affect the functional capabilities of plants to perform in the stress environment or it may suggest the negative effect of stress on protein/gene synthetic machinery.

The comparison of polypeptide profile of early and mid-late sugarcane varieties showed that four polypeptide bands (MW 54.6, 40.45, 27.11 and $22.1 \mathrm{kDa}$ ) appeared at 120 DAP (rewatering). This suggested that polypeptide expression varied depending upon the different developmental stages and the differential gene expression of concerned structural or regulatory gene (s). Our results were also in accordance with Jangpromma $e t$ al., (2010) who reported accumulation of an $18 \mathrm{kDa}$ protein in K86-161 sugarcane line which was subjected to progressive water 
stress for 20 days.

The synthesis and accumulation of most of the polypeptides under moisture stress, in the present study suggests major mechanisms that underlie adaptation or tolerance to osmotic stress.

It is generally assumed that stress induced proteins may play a role in tolerance, but direct evidence is still lacking and the function of many stress responsive genes are unknown. Stress associated proteins are either synthesized de novo in response to stress or present constitutively at low level and their expression increases in response to stress.

\section{Acknowledgement}

The authors are thankful to Regional Director, CCS HAU, Uchani, Karnal for providing the required research facilities and Director, ICAR-SBI, Coimbatore to the senior author is duly acknowledged.

\section{References}

Bradford, M.M., 1976. A rapid and sensitive method for the quantization of microgram quantities of protein utilizing the principle of protein dye binding. Analytical Biochemistry, 72, 248-254.

Bray, E.A., 2001. Plant responses to water deficit stress. Encyclopedia of Life Sciences, pp. 1-5.

Chandra, A., and Tyagi, A. 2004. Protein profiles of two rice varieties by 2-D gel electrophoresis under moisture stress. Indian J. Biochem. Biophysics. 41: 191194.
Commodity Research Bureau. 2015. The 2015 CRB commodity yearbook. Chicago, IL: Commodity Research Bureau.

Jangpromma, N., Kitthaisong, S., Lomthaisong, K., Daduang, S., Jaisil, P. and Thammasirirak, I. 2010. A proteomics analysis of drought stress responsive proteins as biomarker for drought-tolerant sugarcane cultivars. Am. J. Biochem. Biotechnol, 6: 89-102.

Joshi, R., Shukla, A. and Kumar, P. 2013. In vitro water deficit stress induced genotypic alterations in protein profile among aromatic rice varieties. Annals of Plant Sciences, 02(10): 455-458.

Kiegle. E., Moore. C.A., Haseloff, J., Tester, M.A. and Knight, M.R. 2000. Cell-type specific calcium responses to drought, salt and cold in the Arabidopsis root. Plant Journal. 23: 267-278.

Kumar, A., Sharma, S.K., Lata, C., Sheokand, S. and Kulshreshta, N. 2015. Combined effect of boron and salt on polypeptide resolutions in wheat varieties differing in their tolerance. Indian Journal of Agricultural Sciences. 85(12): 1626-32.

Laemmli, U.K., 1970. Cleavage of structural proteins during the assembly of the head of the bacteriophage Ty. Nature, 277, 680-685.

Singh, A., Shamim Md, Singh KN 2013. Genotypic variation in root anatomy, starch accumulation, and protein induction in upland rice (Oryza sativa) varieties under water stress, Agric Res., 2: 24-30.

Vision SBI. 2016. Vision 2030, Sugarcane Breeding Institute, Coimbatore - 641 007.

\section{How to cite this article:}

Pooja, A.S. Nandwal, Mehar Chand, Ashwani Kumar, Babita Rani, Anita Kumari and Neeraj Kulshrestha. 2017. Comparative Evaluation of Changes in Protein Profile of Sugarcane Varieties under Different Soil Moisture Regimes. Int.J.Curr.Microbiol.App.Sci. 6(10): 12031210. doi: https://doi.org/10.20546/ijcmas.2017.610.145 